\title{
Calcium Carbide-Induced Haematological Alterations In The Albino Mice- Mus musculus
}

\author{
Dike Henry Ogbuagu ${ }^{1}$, Cosmas Onyekachi Ujowundu ${ }^{2}$, \\ Lucy Chinomso Izunobi ${ }^{1}$ \\ ${ }^{I}$ (Department of Environmental Technology, Federal University of Technology, Owerri, Nigeria) \\ ${ }_{2}^{2}$ (Department of Biochemistry, Federal University of Technology, Owerri, Nigeria)
}

\begin{abstract}
Calcium carbide $\left(\mathrm{CaC}_{2}\right)$, a chemical often misused by local fruit vendors in Nigeria to stimulate artificial ripening, was tested on mammalian model for possible haematological inductions. Thirty male albino mice (Mus musculus) of isogenic strains (age $\approx 8$ weeks; weight $=32.5 \pm 2.0 \mathrm{~g}$ ) were acclimatized for 2 weeks and fed standard growers mash and water ad libitum at ambient temperature $\approx 28.0 \pm 1.0^{\circ} \mathrm{C}$. They were subsequently exposed to graded $\mathrm{CaC}_{2}$-in-feed concentrations $(\mathrm{w} / \mathrm{w})$ of 2.5000, 1.2500, 0.6250, and 0.3125\% in 4 cages, and a control. After 5 weeks, 3 animals from each cage were assayed and blood cell counts determined by microscopic procedures. The ANOVA, means plots, Student's t-test and variation plots were used to analyze data. The higher toxicant concentrations induced significantly lower body weights $\left[F_{(829.899)}>F_{\text {crit }(4.19)]}\right.$ at $p<0.05$. Lower leucocytes and slightly higher lymphocytes were counted in dosed animals than control. The near absence of monocytes and complete absence of basophils indicate slight immunological inductions on the mammals.
\end{abstract}

Keywords: Calcium carbide, fruit vendors, haematological inductions, artificial ripening

\section{Introduction}

Pure calcium carbide $\left(\mathrm{CaC}_{2}\right)$ is colourless, though most of the industrially produced impure ones, depending on the quality, are black or grayish-white in colour. It is mainly used in the production of flammable acetylene gas for welding and fabrication works. Once in contact with moisture, $\mathrm{CaC}_{2}$ releases acetylene, which also has fruit ripening characteristics similar to ethylene [1] according to the reaction:

$\mathrm{CaC}_{2}+2 \mathrm{H}_{2} \mathrm{O} \rightarrow \mathrm{Ca}(\mathrm{OH})_{2}+\mathrm{C}_{2} \mathrm{H}_{2} \ldots \ldots \ldots \ldots . . \mathrm{i}$

Naturally, fruits ripen by the action of a ripening hormone, during which process a wide spectrum of biochemical changes such as chlorophyll degradation and biosynthesis of carotenoids (which are antioxidants, immune system boosters and anti-cancer agents), anthocyanins (powerful antioxidants), essential oils, as well as flavour and aroma components takes place [2]. A similar action is induced by $\mathrm{CaC}_{2}$ in artificial conditions.

Fruit vendors especially in our cities have thus used carbide gas from $\mathrm{CaC}_{2}$ to ripen fruits, a practice CAP [2] stated could portend hazard to the human body, especially as the chemical could also contain traces of arsenic and phosphorus. Fattah and Ali [3] have observed that direct consumption of acetylene could be detrimental as it reduces oxygen supply to the brain and can further lead to prolonged hypoxia. Further, impurities like arsenic and phosphorus found in industrial grade $\mathrm{CaC}_{2}$ may cause serious health hazards among workers who are in direct contact with these chemicals while applying the ripening agent. Effects may include dizziness, frequent thirst, irritation in mouth and nose, weakness, permanent skin damage, difficulty in swallowing, vomiting, and skin ulcer, among others. The United States Department of Health [4] states that higher exposures may even cause pulmonary edema, and Kjuus et al. [5] observed that chemicals including $\mathrm{CaC}_{2}$ and acetylene gas also show other adverse effects including memory loss, neurological system failure, and cerebral edema. Other effects especially from contaminated foods include colonic lung cancer, quick-buck syndrome, DNA, RNA and hematological changes [6][7], as well as proliferation of bacteria, fungi and viruses which can cause diarrhea, peptic ulcer and other human diseases.

Against the banning of ripening fruits with carbide in many countries [7], the practice is still freely used in some places in Nigeria, where fruit farmers, vendors and wholesalers use the gas to ripen a variety of fruits such as bananas, mangoes, pineapples, and papayas in commercial centres and market places. During this process, contamination of the fruits with solid $\mathrm{CaC}_{2}$ frequently occurs and could be ingested with the ripened fruit. This work therefore ascertained possible inductions of $\mathrm{CaC}_{2}$ on the haematology of the albino mice, Mus musculus. 


\subsection{Acquisition and Acclimatization of Mammals}

\section{Methodology}

Thirty isogenic strains of male M. musculus, about 8 weeks old and weighing $32.5 \pm 2.0 \mathrm{~g}$ were used as experimental models. The mammals were randomly divided into 5 groups in 530x350x230 $\mathrm{cm}$ bedded (with dry wood shavings) metal cages with perforated roof lids. The wood shavings were changed every day to prevent maggotry. The animals were acclimatized in the Pollution Laboratory of the Federal University of Technology, Owerri, Nigeria at average ambient temperature of $28.0 \pm 1.0^{\circ} \mathrm{C}$ for 2 weeks, during which period they were fed about 20g standard rodent growers mash (produced by Bendel Food and Flour Mills Nigeria Ltd) and water ad libitum. Close watch was made for dead animals which were removed as soon as possible to avoid contamination.

\subsection{Formulation of Toxicant}

Sample of $\mathrm{CaC}_{2}$ obtained from a welding and fabrications workshop in Obinze, Owerri, Nigeria was ground to powder in a dry mortar. Four concentrations of the toxicant, viz, 0.5, 0.25, 0.125 and $0.0625 \mathrm{~g}$ were weighed out and incorporated to make up $20 \mathrm{~g}$ of toxicant-feed mixture each. This translates to 2.5000, 1.2500, 0.6250 and $0.3125 \%$ toxicant concentrations in $20 \mathrm{~g}$ feeds respectively.

\subsection{Dosing of Mammals}

After the initial 2 weeks of acclimatization, 5 mice were distributed into five different cages and labeled $\mathrm{Cg} 1, \mathrm{Cg} 2, \mathrm{Cg} 3, \mathrm{Cg} 4$ and $\mathrm{CgC}$ in descending order of intended toxicant concentrations, with $\mathrm{CgC}$ as the control cage. Thereafter, the animals were fed the different toxicant concentrations i.e. $0.5 \mathrm{~g}(2.5000 \%), 0.25 \mathrm{~g}$ $(1.2500 \%), 0.125 \mathrm{~g}(0.6250 \%)$ and $0.0625 \mathrm{~g}(0.3125 \%)$ in $20 \mathrm{~g}$ toxicant-feed mixture. They were also given water ad libitum.

\subsection{Animal sacrifice and Sampling}

After the 5 weeks (35 days) exposure period, 3 randomly selected mice from each treatment and control cage were weighed. One milliliter syringes with 25 guage needles were used to withdraw $5 \mathrm{~mL}$ blood samples from the right ventricles of the animals. The samples were transferred into heparinized (EDTA-coated) bottles which were subsequently inverted severally to achieve homogenization and prevent clotting.

\subsection{Haematology test}

Haemoglobin concentration $\left(\mathrm{Hb}\right.$ in $\left.\mathrm{gdl}^{-1}\right)$ was determined using the cyanometer-haemoglobin method [8]; total Red Blood Cell count (RBC in $10^{6}$ of cells $\mathrm{mm}^{-3}$ ) was estimated using a haemocytometer counting chamber [8]; White Blood Cells (WBC) were evaluated using an improvised Neubauer counter [9]; and differential counts for lymphocytes, neutrophils, monocytes, basophils and eosinophils were determined from blood film stained with Grumwald-Giemsastain [10].

\subsection{Statistical Analysis}

Variation plot was used to represent numbers of the haematological inductions. The single factor ANOVA was used to determine homogeneity in mean variance of weight and haematological inductions in the different concentrations of the toxicant at $\mathrm{p}<0.05$. Means plots were used to detect structure of group means. The student's t-test was used to make pair-wise comparison in haematological inductions at the $95 \%$ confidence interval.

\subsection{Toxicant concentrations and weight of organisms}

Table 1 shows the weight of the animals in different concentrations of the toxicant after 5 weeks exposure period. The highest mean weight $(42.59 \pm 2.97 \mathrm{~g})$ of animals was recorded in the $0.6250 \%(0.125 \mathrm{~g}$ of toxicant in $20 \mathrm{~g}$ of feed) concentration, while the least mean weight of $34.97 \pm 1.82 \mathrm{~g}$ was recorded in the 0.3125 $\%(0.00625 \mathrm{~g}$ of toxicant in $20 \mathrm{~g}$ of feed) concentration. Animals exposed to the $2.5000 \%$ ( $0.5 \mathrm{~g}$ toxicant in $20 \mathrm{~g}$ of feed) recorded mean weight of $40.61 \pm 3.87 \mathrm{~g}$, while the mean weight of $39.40 \pm 0.11 \mathrm{~g}$ was recorded in the $1.2500 \%$ ( $0.25 \mathrm{~g}$ of toxicant in $20 \mathrm{~g}$ of feed) concentration. However, animals in the control experimental setup recorded mean weight of $39.60 \pm 1.08 \mathrm{~g}$.

The single factor ANOVA test revealed that the different concentrations of toxicant affected weights of the organisms significantly $\left[\mathrm{F}_{(829.899}>\mathrm{F}_{\text {crit(4.19) }}\right]$ at $\mathrm{p}<0.05$. 
Calcium carbide-induced haematological alterations in the albino mice-Mus musculus

Table 1. Weights of mice (M. musculus) exposed to different concentrations of $\mathrm{CaC}_{2}$ after 5 weeks

\begin{tabular}{|c|c|c|c|c|}
\hline \multicolumn{2}{|c|}{ Weight (g) } \\
$\begin{array}{l}\text { Concentrations/20g of } \\
\text { feed }(\%)\end{array}$ & Replicate 1 & Replicate 2 & Replicate 3 & $\begin{array}{c}\text { Mean } \\
\text { weight } \pm \text { SE }\end{array}$ \\
\hline $0.000 \mathrm{~g}(0.00 \%)$ & 38.93 & 41.72 & 38.16 & $39.60 \pm 1.08$ \\
\hline $0.0625 \mathrm{~g}(0.3125 \%)$ & 38.60 & 32.96 & 33.34 & $34.97 \pm 1.82$ \\
\hline $0.125 \mathrm{~g}(0.6250 \%)$ & 40.54 & 38.78 & 48.45 & $42.59 \pm 2.97$ \\
\hline $0.25 \mathrm{~g}(1.2500 \%)$ & 39.56 & 39.20 & 39.45 & $39.40 \pm 0.11$ \\
\hline $0.5 \mathrm{~g}(2.5000 \%)$ & 42.65 & 33.13 & 46.05 & $40.61 \pm 3.87$ \\
\hline
\end{tabular}

\subsection{Toxicant concentrations and Haematological inductions}

Table 2 shows counts of the haematological parameters measured after 5 weeks exposure period. In the $2.5000 \%$ toxicant concentration, mean WBC count was $7.03 \times 10^{9} / \mathrm{L}$, Hb was $9.87 \mathrm{~g} / \mathrm{dL}$, neutrophils was 50.33 $\%$, and lymphocytes was $49.67 \%$ (Fig. 1). In the $1.2500 \%$ toxicant concentration, mean WBC count was $7.00 \times 10^{9} / \mathrm{L}$, Hb was $9.87 \mathrm{~g} / \mathrm{dL}$, neutrophils was $44.00 \%$ and lymphocytes was $55.00 \%$. Mean WBC count was $10.27 \times 10^{9} / \mathrm{L}$, Hb count was $12.00 \mathrm{~g} / \mathrm{dL}$, neutrophils was $56.00 \%$, lymphocytes was $43.67 \%$ and monocytes was $0.33 \%$ in the $0.625 \%$ toxicant concentration. In the $0.3125 \%$ toxicant concentration, mean $\mathrm{WBC}, \mathrm{Hb}$, neutrophils, lymphocytes and eosinophils were $8.00 \times 10^{9} / \mathrm{L}, 9.87 \mathrm{~g} / \mathrm{dL}, 52.00 \%, 47.33 \%$ and $0.33 \%$ respectively.

However, in the control concentration, the counts were $10.27 \times 10^{9} / \mathrm{L}(\mathrm{WBC}), 9.87 \mathrm{~g} / \mathrm{dL}(\mathrm{Hb}), 54.33 \%$ (neutrophils), $44.67 \%$ (lymphocytes) and $0.33 \%$ (eosinophils). Figure 1 shows mean counts of the heamatological inductions.

Several of the RBCs observed in the blood films had either the normal Normocytic, Normochronic, or Ovalocytic red cell shapes. However, few Hypochronic Red Cell (HRC) abnormalities were observed in films from the mice. They were those in $\mathrm{Cg} 1 \mathrm{~A}$ replicate of the $2.500 \%$ and $\mathrm{Cg} 4 \mathrm{~A}$ replicate of the $0.3125 \%$ toxicant concentrations (Table 3)

Table 2. Haematological parameters (mean \pm SE) of the albino mice (M. musculus) exposed to different concentrations of $\mathrm{CaC}_{2}$ for 5 weeks

\begin{tabular}{lcccccccc}
\hline $\begin{array}{l}\text { \% toricant } \\
\text { concentration } \\
20 \mathrm{~g} \text { of feed }\end{array}$ & $\begin{array}{c}\mathrm{WBC} \\
\left(\mathrm{x} 10^{9} \mathrm{~L}\right)\end{array}$ & $\begin{array}{c}\mathrm{Hb} \\
(\mathrm{g} / \mathrm{dL})\end{array}$ & $\begin{array}{c}\text { Neutrophils } \\
(\%)\end{array}$ & $\begin{array}{c}\text { Lymphocytes } \\
(\%)\end{array}$ & $\begin{array}{c}\text { Eosinophils } \\
(\%)\end{array}$ & $\begin{array}{c}\text { Monocytes } \\
(\%)\end{array}$ & $\begin{array}{c}\text { Basophils } \\
(\%)\end{array}$ \\
\hline $0.0000 \%(\mathrm{CgC})$ & $10.27 \pm 1.78$ & $9.87 \pm 0.24$ & $54.33 \pm 2.73$ & $14.67 \pm 2.33$ & $1.00 \pm 0.58$ & $0.00 \pm 0.00$ & $0.00 \pm .00$ \\
$0.3125 \%(\mathrm{Cg} 4)$ & $8.00 \pm 2.95$ & $9.87 \pm 1.98$ & $52.00 \pm 7.51$ & $44.00 \pm 5.03$ & $0.67 \pm 0.33$ & $0.00 \pm .00$ & $0.00 \pm 0.00$ \\
$0.6250 \%(\mathrm{Cg})$ & $6.63 \pm 1.48$ & $12.00 \pm 0.46$ & $56.00 \pm 36$ & $43.67 \pm 4.41$ & $0.00 \pm 0.00$ & $0.33 \pm 0.33$ & $0.00 \pm 0.00$ \\
$1.2500 \%(\mathrm{Cg} 2)$ & $7.00 \pm 1.19$ & $12.30 \pm 0.44$ & $44.00 \pm 5.69$ & $55.00 \pm 2.31$ & $0.00 \pm 0.00$ & $0.00 \pm 0.00$ & $0.00 \pm 0.00$ \\
$2.5000 \%(\mathrm{Cgl})$ & $7.03 \pm 0.92$ & $10.27 \pm 1.90$ & $50.33 \pm 7.54$ & $49.67 \pm 7.54$ & $0.00 \pm 0.00$ & $0.00 \pm 0.00$ & $0.00 \pm 0.00$ \\
\hline
\end{tabular}

WBC $=$ White Blood Cell, $\mathrm{Hb}=$ Haemoglobin concentration

However, the various toxicant concentrations used did not induce significantly different haematological counts, especially when statistical comparisons were made between counts in the $\mathrm{Cg} 1$ and Control groups $(\mathrm{t}=0.793), \mathrm{Cg} 2$ and control groups $(\mathrm{t}=0.947), \mathrm{Cg} 3$ and control groups $(\mathrm{t}=0.876)$, and $\mathrm{Cg} 4$ and Control groups $(\mathrm{t}=0.686)$ at $\mathrm{P}<0.05$. 


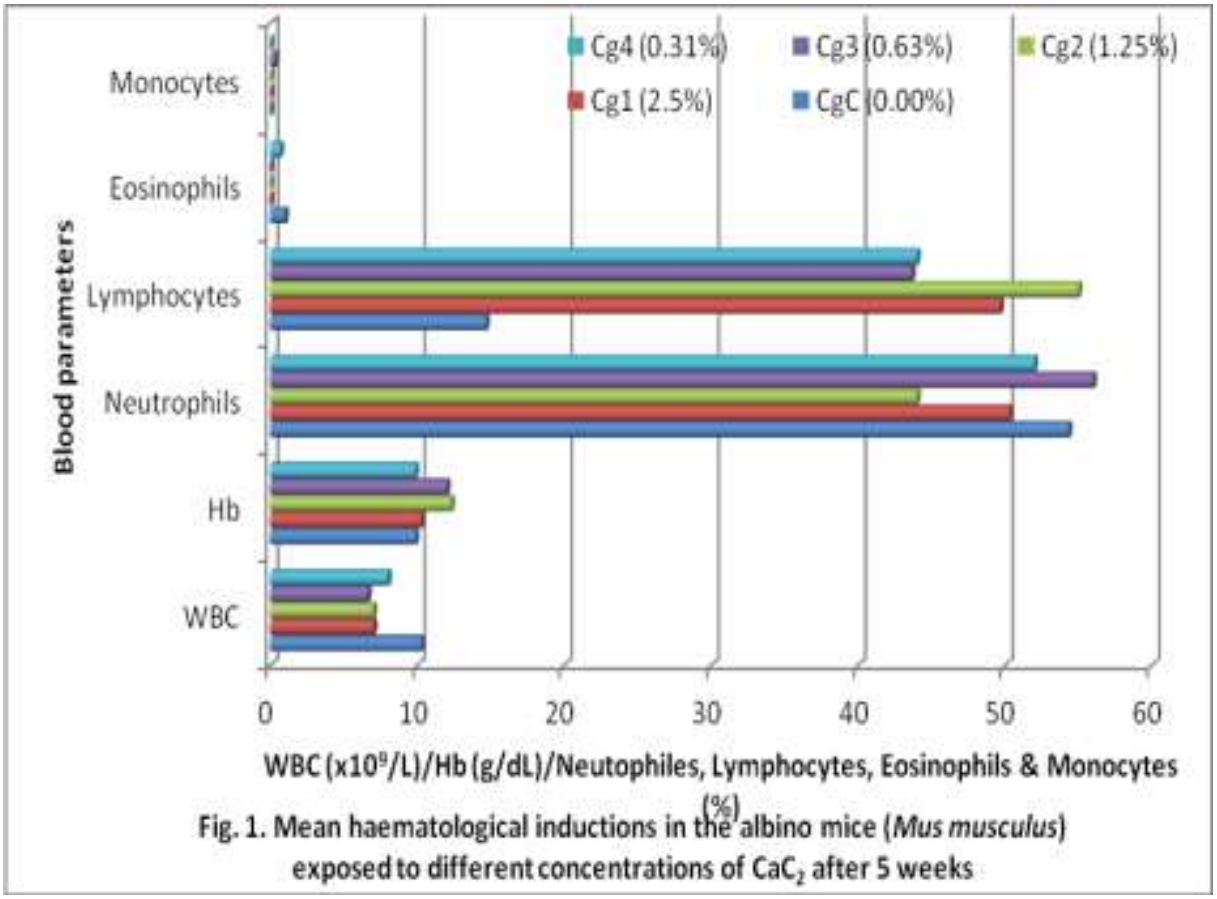

Table 3. Morphological deficiencies in red blood cells of the albino mice (M. musculus) exposed to different concentrations of $\mathrm{CaC}_{2}$ for 5 weeks

\begin{tabular}{|c|c|c|c|}
\hline $\begin{array}{l}\text { Toxicant } \\
\text { Concentration }(\%)\end{array}$ & Replicates & Blood film morphometry & Normality \\
\hline $2.500 \%$ & $\begin{array}{l}\text { Cg1A } \\
\text { Cg1B } \\
\text { Cg1C }\end{array}$ & $\begin{array}{l}\text { Normocytic and HRCs } \\
\text { Normocytic and Normochronic red cells } \\
\text { Ovalocytic and Normochronic cells }\end{array}$ & $\begin{array}{c}\text { Abnormal HRCs } \\
\text { Normal } \\
\text { Normal }\end{array}$ \\
\hline $1.250 \%$ & $\begin{array}{l}\mathrm{Cg} 2 \mathrm{~A} \\
\mathrm{Cg} 2 \mathrm{~B} \\
\mathrm{Cg} 2 \mathrm{C}\end{array}$ & $\begin{array}{l}\text { Normochronic and Normocytic cells } \\
\text { Normochronic and Normocytic cells } \\
\text { Normochronic and Normocytic cells }\end{array}$ & $\begin{array}{l}\text { Normal } \\
\text { Normal } \\
\text { Normal }\end{array}$ \\
\hline $0.625 \%$ & $\begin{array}{l}\text { Cg3A } \\
\text { Cg3B } \\
\text { Cg3C }\end{array}$ & $\begin{array}{l}\text { Normochronic and Normocytic cells } \\
\text { Normochronic and Normocytic cells } \\
\text { Normochronic and Normocytic cells }\end{array}$ & $\begin{array}{l}\text { Normal } \\
\text { Normal } \\
\text { Normal }\end{array}$ \\
\hline $0.3125 \%$ & $\begin{array}{l}\text { Cg4A } \\
\text { Cg4B } \\
\text { Cg4C }\end{array}$ & $\begin{array}{l}\text { Normocytic and HRCs } \\
\text { Normochronic and Normocytic cells } \\
\text { Normochronic and Normocytic cells }\end{array}$ & $\begin{array}{l}\text { Abnormal HRCs } \\
\text { Normal } \\
\text { Normal }\end{array}$ \\
\hline $0.000 \%$ (Control) & $\begin{array}{l}\text { Cg2A } \\
\text { Cg2B } \\
\text { Cg2C }\end{array}$ & $\begin{array}{l}\text { Normochronic and Normocytic cells } \\
\text { Normochronic and Normocytic cells } \\
\text { Normochronic and Normocytic cells }\end{array}$ & $\begin{array}{l}\text { Normal } \\
\text { Normal } \\
\text { Normal }\end{array}$ \\
\hline
\end{tabular}

HRCs=Hypochronic Red blood Cells

\section{Discussion}

The toxicant appeared to induce slight body weight gains, especially in the organisms exposed to the higher concentrations of the chemical after five weeks exposure period. Weight is often used as a vital sign of health status of organisms. According to Chevrier et al. [11], while there appear to be a consensus among scientists and clinicians that body weight loss reduces the risk of several chronic diseases, this apparently 
favourable effect should be balanced against any potentially harmful side effects of weight loss. Their warning derives from an observation that weight loss produced an increase in blood concentration of potentially toxic organochlorine pollutants in animals that can causes elevated plasma and subcutaneous adipose tissue concentrations of the pollutants in obese subjects.

Adhikari et al. [12] and Ogbuagu et al. [13] had observed that haematological parameters are pathophysiological reflectors of the whole body of an organism (fish), even as Alimba et al. [14] stated that one among the validated methods for investigating the immune-toxic potentials of toxicants, primarily in rodents is change in cellular components of blood. Comparatively lower white blood cell counts were recorded in mice exposed to toxicant concentrations than the unexposed group. Similar dose-dependent inductions of the immune system had been observed in humans exposed to marijuana smoke [15], and marijuana and tobacco [16], as well as in mice orally exposed to 2-ethoxy ethyl acetate [17].

Given the important immunological defense role played by leucocytes against pathogens and other foreign substances [18], depletion, or even sudden elevation in their number (as in leukocytosis) could therefore indicate response to foreign invasion of the organism's system. This observation is further reflected in the counts of the leucocyte types, such as slightly higher lymphocytes in the dosed mammals and one monocyte in the $0.625 \%$ toxicant concentration and non in control setup.

The few hypochronic red blood cells observed as well as the near absence of monocytes and complete absence of basophils confirm minor immunological inductions on the mammals.

\section{Summary}

This research revealed a slight increase in weights of mice exposure to $\mathrm{CaC}_{2}$ for 5 weeks. Fewer white blood cells were counted in dosed animals, with slightly higher lymphocytes and few abnormal hypochronic red blood cells in exposed animals than in the control group.

\section{Conclusion}

$\mathrm{CaC}_{2}$ induced slight immunological response in the albino mice-M. musculus.

\section{Acknowledgements}

The authors are grateful to the Department of Biochemistry, Federal University of Technology Owerri for providing some materials used in this study. We are also indebted to Ejimedicals Diagnostic Laboratories in Owerri, for their assistance in haematology analyses.

[1] M Asif, Physico-chemical Properties and Toxic Effect of Fruit Ripening against Calcium Carbide, Annals of Tropical Medicine and Public Health, 5, 2012, 150-160.

[2] Consumers Association of Penang (CAP), Ban the Use of Carbide to Ripen Fruits, Retrieved July 20, 2014 from http://www.consumers.org.my/index.php/food/safety/502.

[3] S.A. Fattah, M.Y. Ali, Carbide Ripened Fruits -A Recent Health Hazard, Faridpur Medical College Journal, 5(2), $2010,37$.

[4] USA Department of Health (USDH), Description of a Hazardous Substance, Fact Sheet, USA: Trenton, NJ. $2000, p .1$-4.

[5] H. Kjuus, A. Andersen, S. Langard, Incidence of Cancer among Workers Producing Calcium Carbide. Porsgrunn and the Cancer Registry of Norway, Norway, 2007.

[6] W.S. Rahman, M.B. Chowdhurry, Artificial Ripening: What we are Eating. Journal of Medicine, 9, 2008, 42-44.

[7] A.J. Dhembare, A.B. Gholap, V. Vandana, Bitter Truth About Artificial Ripener. Journal of Experimental Zoology India, 14(1), 2011, 187-189.

[8] M.K. Stoskopf, Clinical pathology. In Stoskopf MK, Saunders WB (eds), Fish medicine. Philadelphia: WB Saunders, Pp113-131, 1993.

[9] A.J. Yaji, J. Auta, Sublethal effects of monocrotophos on some haematological indices of African catfish Clarias gariepinus, Journal of Fisheries International, 2, 2007, 115-117.

[10] E.F. Hesser, Methods for routine fish haematology. The Progressive Fish-Culturist, 22, 1960, $164-171$.

[11] J. Chevrier, E. Dewailly, P. Ayotte, P. Mauriege, J.P. Despres, A. Tremblay, Body Weigh Los Increases Plasma and Adipose Tissue Concentrations of Potentially Toxic Pollutants in Obese Individuals, International Journal of Obesity, 24 (10), 2000, 1272-1278.

[12] S. Adhikari, B. Sarkar, A. Chatterjee, C.T. Mahapatra, S. Ayyappan, Effects of cypermethrin and carbofuran on certain haematological parameters and prediction of their recovery in a fresh water teleost, Labeorohita (Hamilton). Ecotoxicology and Environmental Safety, 58, 2004, 220-226.

[13] D.H. Ogbuagu, E.T. Adebayo, A.A. Ayoade, O.B. Ugwu, D.O. Mba, Lead accumulation in and its haematological effects on African catfish Clarias gariepinus, African Journal of Aquatic Science, 40(2), 2015, 1-4.

[14] C.G. Alimba, A.A. Bakare, O.G. Arinola, Effects of municipal solid waste leachate on leucocyte and differential counts in rats, Global Journal of Environmental Research, 3 (3), 2009, 135-140.

[15] S.O. Oseni, V.A. Togun, O.F. Taiwo, Effect of marijuana smoking on some haematological parameters of smokers, World Journal of Medical Sciences, 1, 2006, 82-85.

[16] B.A. Moore, E.M. Augustson, R.P. Moser, A.J. Budney, Respiratory effects of marijuana and tobacco use in US samples., Journal of General Internal Medicine, 20, 2005, 33-37.

[17] K. Nagano, E. Nakayama, H. Obayashi, Experimental studies on toxicity of ethylene glycol monomethyl ether in Japan, Experimental Health Perspective, 57, 1984, 75-84.

[18] C. Ohnmacht, D. Voehringer, Basophil effector function and homeostasis during helminth infection. Blood, 113(12), 2009, 28162825 . 